EFEKTIFITAS EKSTRAK BUAH MENGKUDU (Morinda Citrifolia L) TERHADAP PENURUNAN KOLONI JAMUR C.albicans PADA MENCIT YANG TERPAPAR C.albicans

JURNAL KESEHATAN

http://ejournal.poltekkesternate.ac.id/ojs

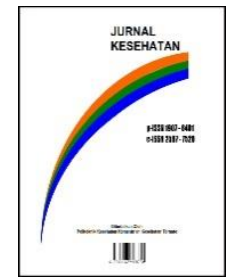

\title{
EFEKTIFITAS EKSTRAK BUAH MENGKUDU (Morinda Citrifolia L) TERHADAP PENURUNAN KOLONI JAMUR C.albicans PADA MENCIT YANG TERPAPAR C.albicans
}

\author{
Reny Retnaningsih ${ }^{1 \bowtie}$, Anik Sri Purwanti² \\ ${ }^{1}$ Politeknik Kesehatan RS dr Soepraoen Kesdam V/Brawijaya \\ 1renyretna87@gmail.com
}

\begin{abstract}
Info Artikel
Sejarah Artikel:

Diterima Sept 2019

Disetujui Okt 2019

Di Publikasi Nov 2019

Keywords:

Petunjuk Penulisan ;

Jurnal Kesehatan;

Template Artikel

( Terdiri dari 3-5 kata )

\section{Abstrak}

Infeksi vagina dapat terjadi dikarenakan pertumbuhan yang tidak terkendali dari jamur $C$. albicans.. Kandungan antrakuinon dalam buah mengkudu (Morinda citrifolia L.) mempunyai efek farmakologik sebagai lisosim terhadap jamur. Tujuan penelitian ini adalah mengetahui efektifitas ekstrak buah mengkudu (Morinda Citrifolia L) terhadap penurunan koloni jamur C.albicans pada mencit yang terpapar C.albicans. Desain penelitian true eksperimental dengan rancangan pre-post test randomized control group design. Sampel dari penelitian ini adalah mencit (Mus musculus) betina, usia 2-3 bulan, dengan berat 20-25 gram, diinfeksi C.albicans. Menggunakan empat perlakuan dan enam kali pengulangan. Perlakuan yang digunakan adalah kontrol negatif (tanpa ekstrak buah mengkudu (Morinda citrifolia L.) dan kontrol positif (pemberian ekstrak buah mengkudu (Morinda citrifolia L.) dengan dosis yang berbeda, yaitu $50 \mathrm{mg} / \mathrm{kg} \mathrm{BB}, 100 \mathrm{mg} / \mathrm{kg} \mathrm{BB}, 200$ $\mathrm{mg} / \mathrm{kg} \mathrm{BB}$ ). Jumlah koloni jamur diamati dengan metode pour Plate Slide. Hasil penelitian menunjukkan. Analisis menggunakan one way ANOVA atau uji alternative Kruskal-Wallis. Hasil penelitian menunjukkan terdapat penurunan koloni jamur yang tidak signifikan pada kelompok perlakuan pemberian ekstrak buah mengkudu dosis $50 \mathrm{mg} / \mathrm{kgBB}, 100 \mathrm{mg} / \mathrm{kgBB}$ dan $200 \mathrm{mg} / \mathrm{kgBB}$, meskipun secara deskriptif terjadi penurunan rata-rata koloni jamur pada semua kelompok perlakuan. p-value lebih dari 0,05 ( $\mathrm{p}>0,05)$. Ekstrak buah mengkudu dapat bermanfaat untuk meningkatkan imunitas tubuh dalam mengatasi infeksi jamur.
\end{abstract}

Kata kunci : Buah Mengkudu (Morinda citrifolia L.), Infeksi Jamur, Koloni Candida albicans

\begin{abstract}
Vaginal infections can occur due to uncontrolled growth of the fungus C. albicans. The anthraquinone content in the Noni fruit (Morinda citrifolia L.) has a pharmacological effect as a lysozyme against the fungus. The purpose of this study was to determine the effectiveness of Noni Fruit (Morinda Citrifolia L) extracts on the reduction of C.albicans fungal colonies in mice exposed to C.albicans. The true experimental research design was a randomized control group design pre-post test. The sample of this study was female mice (Mus musculus), aged 2-3 months, weighing 20-25 grams, infected with C. albicans. Using four treatments and six repetitions. The treatments used were negative control (without noni extract (Morinda citrifolia L.) and positive control
\end{abstract}


EFEKTIFITAS EKSTRAK BUAH MENGKUDU (Morinda Citrifolia L) TERHADAP PENURUNAN KOLONI JAMUR C.albicans PADA MENCIT YANG TERPAPAR C.albicans

(administration of noni fruit extract (Morinda citrifolia L.) with different doses, namely $50 \mathrm{mg} / \mathrm{kg}$ weight, $100 \mathrm{mg} / \mathrm{kg}$ weight, $200 \mathrm{mg} / \mathrm{kg}$ weight). The number of fungal colonies was observed by Pour Plate Slide method. The results showed that the analysis used one way ANOVA or Kruskal-Wallis alternative test. The results showed that there was no significant decrease in fungal colonies in the treatment group giving noni dose extract $50 \mathrm{mg} / \mathrm{kg}$ weight, $100 \mathrm{mg} / \mathrm{kg}$ weight and $200 \mathrm{mg} / \mathrm{kg}$ weight, although descriptively there was an average decrease in fungal colonies in all treatment groups, $p$-value more than $0.05(\mathrm{p}>0.05)$. Noni fruit extract can be beneficial to enhance the body's immunity in overcoming fungal infections.

Keywords : Noni Fruit (Morinda citrifolia L.), fungal infection, Colonies C.albicans

(C) 2019 Poltekkes Kemenkes Ternate

Alamat korespondensi:

Poltekkes Kemenkes Ternate, Ternate - West Maluku Utara, Indonesia

ISSN 2597-7520

Email: uppmpoltekkesternate@gmail.co.id

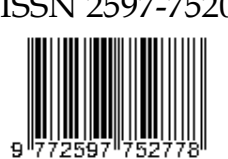


EFEKTIFITAS EKSTRAK BUAH MENGKUDU (Morinda Citrifolia L) TERHADAP PENURUNAN KOLONI JAMUR C.albicans PADA MENCIT YANG TERPAPAR C.albicans

\section{PENDAHULUAN}

Infeksi pada vulva dan vagina dapat

terjadi dikarenakan pertumbuhan yang tidak terkendali dari jamur Candida albicans. Jamur ini menyebabkan wanita mengalami Kandidiasis Vulvovaginitis (KVV). 40\% prevalensi keputihan pada wanita disebabkan oleh kandidiasis dengan ciri keputihan berwarna putih seperti susu, kental, bau dan disertai rasa gatal yang hebat pada kemaluan. Di Indonesia, 50 - $75 \%$ wanita pernah mengalami kandidiasis, 11,2-28,9\% diantaranya adalah akseptor KB IUD (Jessica, et al, 2016).Metode kontrasepsi yang paling banyak digunakan di Indonesia adalah IUD (Intra Uterine Device). Metode ini paling banyak digunakan karena aman, mudah dan lebih menghemat biaya. Chassot menyatakan bahwa penggunaan KB IUD dapat meningkatkan pertumbuhan Candida albicans. Tumbuhnya Candida albicans pada bagian dari IUD dan pembentukan biofilm adalah factor penting yang mempengaruhi terjadinya KKV dan KKV berulang (Sungkar, 2016).

Pengobatan terhadap infeksi jamur dan bakteribiasanya menggunakan obat sintetik seperti menggunakan antibiotik. Ketidaksesuaian dosis dan penggunaan yang tidak teratur dapat mengakibatkan terjadinya resistensi. Munculnya masalah resistensi akan menambah daftar masalah yang belum terselesaikan, sehingga dibutuhkan pengembangan obat-obatan berbahan alam untuk membunuh bakteri dan mencegah terjadinya resistensi (Ilyas, 2008).

Salah satu tanaman yang banyak tumbuh di Indonesia adalah Mengkudu (Morinda citrifolia L.). Tanaman ini sangat potensial untuk dijadikan tanaman obat. Menurut data Direktorat Jenderal Tanaman Pangan dan Hortikultura, pada tahun 2004 luas panen tanaman mengkudu di Jawa Barat mencapai 2,581 ha dengan produksi 3.509,087 ton atau produktivitas tanaman $4,83 \mathrm{~kg} / \mathrm{m} 2$ (Simatupang, et al, 2017).Kandungan antrakuinon dalam buah mengkudu (Morinda citrifolia L.) terbukti mempunyai efek farmakologik sebagai lisosim terhadap sel bakteri dan jamur. Aloin, emodin, barbaloin, saponin, tannin dan sterol merupakan campuran kandungan dalam antrakuinon yang bersinergi dan berkontribusi menjadi suatu khasiat penyembuh yang bersifat analgesik, antiseptik, antiinflamasi, antibakteri dan antijamur (Simatupang, et al, 2017).

Berdasarkan penelitian Ramschie, et al (2017) membuktikan bahwa secara in vitro kandungan antraquinon, minyak atsiri, saponin, tannin, alkaloid, flavonoid, polifenol dan sterol terbukti dapat menghambat pertumbuhan Candida albicans. Berdasarkan latar belakang tersebut, maka peneliti tertarik untuk melakukan penelitian mendalam secara in vivo tentang "Efektivitas Ekstrak Buah Mengkudu (Morinda Citrifolia L.) Terhadap Penurunan Koloni Jamur Candida albicans Pada Mencit Yang Terpapar Candida albicans. 
EFEKTIFITAS EKSTRAK BUAH MENGKUDU (Morinda Citrifolia L) TERHADAP PENURUNAN KOLONI JAMUR C.albicans PADA MENCIT YANG TERPAPAR C.albicans

\section{METODE}

Jenis penelitian true eksperimental dengan rancangan pre-post test randomized control group design. Perlakuan dengan empat kali perlakuan dan tiga kali pengulangan. Sampel dari penelitian ini adalah mencit (Mus musculus), betina,usia 2-3 bulan, berat 20-25 gram. Besar sampel sebanyak 24 ekor.

Setelah 24 ekor mencit diaklimatisasi selama 1 minggu, tikus dibagi menjadi 4 kelompok secara acak, masing-masing kelompok sebanyak 6 ekor dengan dosis 50 $\mathrm{mg} / \mathrm{kg} \mathrm{BB}, 100 \mathrm{mg} / \mathrm{kg}$ BB dan $200 \mathrm{mg} / \mathrm{kg} \mathrm{BB}$ sebanyak 1 kali per hari.

Pembuatan ekstrak buah mengkudu dilakukan di Laboratorium Farmasi Poltekkes RS dr Soepraoen dengan proses maserasi.

Jamur Candida albicans berasal dari Balai Laboratorium Kesehatan dan Kalibrasi Yogyakarta yang telah dilakukan pengujian pada tanggal 18 - 22 Juni 2019.

Mencit diimunosupresi dengan cara mmberikan prednisolon (PDS) dengan dosis $100 \mathrm{mg} / \mathrm{kg}$ BB (2-3 mg/mencit) secara subkutan sehari sebelum diinfeksi Candida albicans. Tetrasiklin hidroklorid diberikan dalam air minum $(0,83 \mathrm{mg} / \mathrm{ml})$ sejak sehari sebelum diinfeksi. Cotton bud dimasukkan ke dalam suspense Candida albicans (2,5 x 107 $\mathrm{sel} / \mathrm{ml}$ yang diukur dengan haematositometer) dan diulaskan ke seluruh permukaan vagina untuk menimbulkan infeksi. Jumlah koloni jamur diamati dengan metode pour Plate Slide.

Perlakuan secara oral dengan menggunakan spuit injeksi 3 ml yang ujungnya dilengkapi kanul.

Penelitian di lakukan di Laboratorium Farmakologi Politeknik Kesehatan RS dr Soepraoen untuk pembuatan ekstrak daun kelor (Moringa oleifera). Penelitian dilakukan di Laboratorium Fisiologi Hewan Fakultas Saintek UIN MALIKI Malang. Penelitian dilaksanakan selama 24 hari setelah lulus dari uji etik.

\section{HASIL PENELITIAN}

Deskripsi Pengamatan Koloni Jamur di Vaginal Lavage Mencit

Sampel yang digunakan berupa vaginal lavage yang telah diuji menggunakan metode Pour Plate Slide yang sudah melalui proses pewarnaan gram yang selanjutnya dilakukan penghitungan koloni jamur.

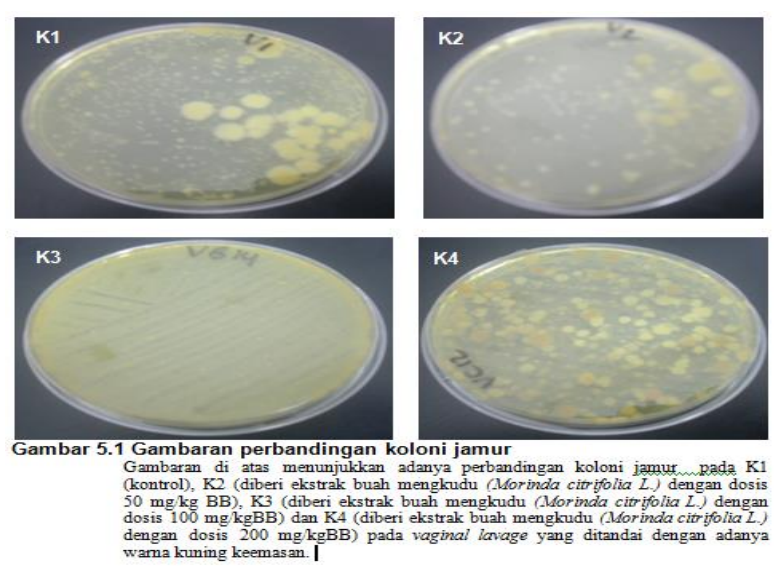

Kelompok (K2) dengan dosis $50 \mathrm{mg} / \mathrm{kg}$ BB menunjukkan penurunan koloni jamur. Kelompok (K3) dengan dosis $100 \mathrm{mg} / \mathrm{kgBB}$ menunjukkan penurunan penurunan koloni 
EFEKTIFITAS EKSTRAK BUAH MENGKUDU (Morinda Citrifolia L) TERHADAP PENURUNAN KOLONI JAMUR C.albicans PADA MENCIT YANG TERPAPAR C.albicans

bila dibandingkan dengan kelompok perlakuan

K2. Kelompok (K4) dengan dosis 200 $\mathrm{mg} / \mathrm{kgBB}$ menunjukkan peningkatan koloni jamur bila dibandingkan dengan kelompok perlakuan K3 namun tetap lebih turun dibandingkan kelompok kontrol. Koloni bakteri antara kelompok kontrol dan kelompok perlakuan baik dengan dosis 125,250 dan 500 $\mathrm{mg} / \mathrm{kgBB}$ menunjukkan hasil yang berbeda yaitu menurunnya koloni bakteri.

\section{Analisis Data Efektivitas Ekstrak Buah} Mengkudu (Morinda Citrifolia L) terhadap Koloni Jamur di Vaginal Lavage

Berdasarkan hasil analisis dengan menggunakan uji Kruskal-Wallis, menunjukkan bahwa tidak terdapat perbedaan yang signifikan koloni jamur pada mencit model infeksi Candida albicans antara kelompok kontrol dengan kelompok perlakuan pemberian buah mengkudu dengan dosis 50 $\mathrm{mg} / \mathrm{kg} \mathrm{BB}, 100 \mathrm{mg} / \mathrm{kgBB}, 200$ mg/kgBB. Hal ini ditunjukkan dengan nilai $p$-value $=0,217$, lebih besar daripada $\alpha=0,05(\mathrm{p}<0,05)$.

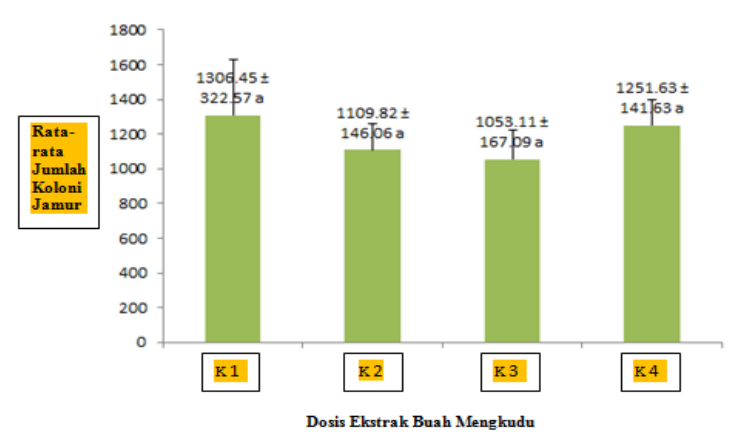

Pada gambar 5.1 menunjukkan histogram rata-rata koloni jamur pada kelompok kontrol kelompok perlakuan pemberian buah mengkudu dengan dosis $50 \mathrm{mg} / \mathrm{kg} \mathrm{BB}, 100$ mg/kgBB, 200 mg/kgBB. Tampak ada penurunan dosis pemberian ekstrak buah mengkudu seiring dengan penurunan rata-rata koloni jamur. Adapun rata-rata koloni jamur terendah pada kelompok perlakuan pemberian ekstrak daun turi merah dosis $100 \mathrm{mg} / \mathrm{kgBB}$ $\left(1053,11 \pm 167,09^{\mathrm{a}}\right)$ dibandingkan dengan kelompok perlakuan yang lain. Hal ini dapat dikatakan bahwa dalam penelitian ini pemberian ekstrak buah mengkudu yang dianggap paling cepat menurunkan koloni jamur pada mencit yang diinfeksi Candida albicans adalah pemberian ekstrak buah mengkudu dosis $100 \mathrm{mg} / \mathrm{kgBB}$.

\section{PEMBAHASAN}

Hasil penelitian menunjukkan bahwa pemberian ekstrak buah mengkudu (Morinda citrifolia L) berpengaruh menurunkan koloni jamur pada mencit yang diinfeksi Candida albicans. Berdasarkan pada hasil analisis dengan menggunakan ANOVA, didapatkan pvalue sebesar 0.217 , lebih besar daripada $\alpha=$ $0,05(\mathrm{p}>0,05)$. Sehingga dari pengujian ini dapat disimpulkan bahwa terjadi penurunan koloni jamur namun tidak signifikan akibat pemberian ekstrak buah mengkudu (Morinda citrifolia $L$ ) dengan dosis yang berbeda.

Dalam keadaan normal, pada vagina juga ditemukan Streptococcus hemolyticus group B, Streptococcus anaerob (Peptostreptococcus), spesies Bacteroides, Clostridia, Gardnelia 
EFEKTIFITAS EKSTRAK BUAH MENGKUDU (Morinda Citrifolia L) TERHADAP PENURUNAN KOLONI JAMUR C.albicans PADA MENCIT YANG TERPAPAR C.albicans

(Haemophillus) vaginalis, Ureaplasma urealyticum dan kadang-kadang Listeria atau spesies Mobilincus (Martin, et al., 2008; Curran, 2010; Preti and Malani, 2010; Naesens, 2013). Flora normal merupakan faktor penting dalam pertahanan anti infeksi pada ekosistem vagina. Jumlah flora normal berubah-ubah selama kehidupan wanita yang dipengaruhi oleh hormon saat hamil dan setelah melahirkan, aktivitas seksual serta penyakit Flora normal memiliki peran dalam menyusun mekanisme protektif host. Bakteri residen yang non pathogen memerlukan kebutuhan ekologi untuk hidupnya sehingga bakteri pathogen (non residen) yang akan berproliferasi di lokasi yang dihuni flora normal akan kesulitan bersaing dengan bakteri residen. Namun jika flora normal tertekan, pertumbuhan bakteri pathogen akan semakin pesat dan dapat menyebabkan penyakit (Wijayani, 2008).

Menurut Ilyas 2008, dengan didasarkan beberapa penelitian sebelumnya tentang potensi buah mengkudu, menyatakan bahwa sari buah mengkudu dapat menghambat pertumbuhan Candida albicans. Hal ini dikarenakan dalam buah mengkudu mengandung senyawa kimia yaitu flavonoid, saponin dan minyak atsiri. Senyawa tersebut berfungsi sebagai antibakteri dan anti jamur.

Senyawa kimia flavonoid merupakan senyawa fenol yang dapat mengakibatkan kerusakan membran sel sehingga terjadi kebocoran isi sel yang dapat mengakibatkan lisis. Senyawa kimia saponin bersifat sebagai surfaktan yang berbentuk polar yang berfungsi untuk memecah lapisan lemak pada membran yang dapat menyebabkan gangguan permeabilitas membran sel kuman. Hal tersebut menyebabkan masuknya bahan atau zat-zat yang diperlukan dapat terganggu sehingga mengakibatkan sel membengkak dan pecah. Minyak atsiri menyebabkan denaturasi protein dimana dapat merubah molekul protein atau asam lemak, menghambat kerja enzim dan mengganggu sintesis asam nukleat (Dewanti, et al, 2005 ; Sabir, 2005 ; Siswomihardjo, 2005 dalam Ilyas, 2008).

\section{SIMPULAN}

1. Pemberian ekstrak buah mengkudu (Morinda citrifolia L) melalui potensi immunomodulator dan antijamur dapat menurunkan koloni jamur pada mencit (Mus musculus) yang diinfeksi Candida albicans.

2. Dosis optimal penggunaan ekstrak buah mengkudu (Morinda citrifolia L) terhadap jumlah koloni jamur pada mencit (Mus musculus) yang diinfeksi Candida albicans adalah $100 \mathrm{mg} / \mathrm{kgBB}$.

\section{UCAPAN TERIMAKASIH}

Peneliti mengucapkan terimakasih kepada Kemenristekdikti atas hibah DRPM Dikti.

\section{REFERENSI}

1. Jessica, Priscilla., Widyawati., Armalina, 
EFEKTIFITAS EKSTRAK BUAH MENGKUDU (Morinda Citrifolia L) TERHADAP PENURUNAN KOLONI JAMUR C.albicans PADA MENCIT YANG TERPAPAR C.albicans

Desy,. 2016. Hubungan Antara Terjadinya

Kandidiasis Vulvovaginalis Dengan

Penggunaan Kontrasepsi Hormonal.

Jurnal Kedokteran Diponegoro. Volume 5,

Nomor 4.

2. Sungkar, Manal Ali. 2016. Hubungan Antara Pemakaian Alat Kontrasepsi Dalam Rahim Dengan Kejadian Kandidiasis Vulvovaginalis Di Rsud Dr. Moewardi. Naskah Publikasi. Fakultas Kedokteran. Universitas Muhammadiyah Surakarta.

3. Ilyas, Muhammad. 2008. Daya Hambat Ekstrak Buah Mengkudu Terhadap Pertumbuhan Candida Albicans. Dentofasial, V 8 Ol.7, No.1, April 2008:712

4. Ganiswarna, S.G. 1995. Farmakologi DanTerapi. Jakarta: Gaya Baru.

5. Cowan, M.M., 1999, Plant Products asAntimicrobial Agents, ClinicalMicrobiology Review, 12, 4, 564582

6. Ajizah, A. 2004. Sensitivitas SalmonellaTyphimorium Terhadap Ekstrak DaunPsidium Guajavo L. Bio Selective, vol1 No. 1:31-8.

7. Simatupang, Olivia C., Abidjulu, Jemmy., Siagian, Krista V.,. 2017. Uji Daya Hambat Ekstrak Buah Mengkudu (Morinda Citrifolia L.) Terhadap Pertumbuhan Candida Albicans Secara In Vitro. Jurnal E-Gigi (Eg), Volume 5 Nomor 1, JanuariJuni 201.
8. Ramschie, Lisa M. L.., Pieter L. Suling., Krista V. Siagian. 2017. Uji Konsentrasi Hambat Minimum (KHM) Ekstrak Buah Mengkudu (Morinda Citrifolia L.) Terhadap Candida Albicans Secara In Vitro. Jurnal E-Gigi (Eg), Volume 5 Nomor 2, Juli-Desember 2017.

9. Khrisnakumar N.M., Latha P.G., Suja S.R., Rajashekaran. 2015. A Review on the Ethnomedicinal, Therapeutic and Nutraceutical Importance of 'Noni'(Morinda citrifoliaL.). International Journal of Medicinal Plants and Natural Products (IJMPNP). Volume 1, Issue 3, October -December 2015, PP 1-14.

10. Kusumaningtyas, Eni. 2012. Mekanisme Infeksi Candida albicans pada Permukaan Sel. Lokakarya Nasional Penyakit Zoonosis.

11. Fiari, Elsa Diana., Savira, Maya., Sukasiati. 2015. Identifikasi Candida sp. Swab Vagina Pekerja Seks Komersial di Kawasan Jondul Pekanbaru. Bagian Mikrobiologi Fakultas Kedokteran Universitas Riau.

12. Arikunto, Suharsini. 2010. Prosedur Penelitian Suatu Pendekatan Praktik. Jakarta : Rineka Cipta.

13. Zega, Victorson L., Pemsi, M. Wowor., Christi Mambo. 2016. Uji beberapa Dosis Ekstrak Buah Mengkudu (Morinda citrifolia 1.) Terhadap Kadar Glukosa DarahPada Tikus Wistar(Rattus norvegicus)yang diinduksi aloksan. Jurnal 
EFEKTIFITAS EKSTRAK BUAH MENGKUDU (Morinda Citrifolia L) TERHADAP PENURUNAN KOLONI JAMUR C.albicans PADA MENCIT YANG TERPAPAR C.albicans e-Biomedik (eBm). Volume 4, Nomor 2.

Kedokteran Gigi FKG Unair. Edisi Khusus

14. Afiif, F.E., Amilah, S. 2017. Efektivitas temu Ilmiah Nasional IV. p. 321-5.

Ekstrak Daun Mengkudu (Morinda

21. Sabir A. 2005. Pemanfaatan Flavonoid di citrifolia L) dan Daun Sirih (Piper crocatum Ruiz \& Pav) Terhadap Zona Hambat Pertumbuhan Staphylococccus aureus. Stigma Journal of Science. Volume 10 No 1.

15. Kusriningrum, R.S. 2008. Perancangan Percobaan. Surabaya : Airlangga University Press

16. Martin, R., Soberon, N., Vaneechoutte, M., Camino, F. V., Suarez, J. E., 2008. Characterization of Indigenous Vaginal Lactobacilli from Healthy Women as Probiotic Candidates. Journal of The Spanish Society for Microbiology, 11 (4): 261-266

17. Curran, D. 2010. Bacterial Vaginosis. http://emedicine.medscape.com/article/25 4342-overview. download on March, 05, 2016

18. Preeti, N and Malani, M. D. mandell, Douglass and Bannett's Principles and Practice of Infectious Disease. The Journal of The American Medical. 2010, 304 (18): 2067-2071

19. Wijayani, C. 2008. Streptococcus agalactiae. Fakultas Farmasi Universitas Sumatra Utara

20. Boedirahardjo R, Dewanti I. 2005. Kemampuan Morinda citrifolia L dalam menurunkan sel radang pada rongga mulut mencit yang diinduksi luka tusuk. Majalah Bidang Kedokteran Gigi. Majalah Kedokteran Gigi FKG Unair. Edisi Khusus temu Ilmiah Nasional IV. p. 81.

22. Siswomihardjo W. 2005. Saponin getah Plumeria acuminate ait. Sebagai Alternatif bahan devitalisasi jaringan pulpa gigi. Majalah Kedokteran Gigi. Edisi Khusus Temu Ilmiah Nasional IV. p. 13. 